\title{
Kara Havuçun Kurutulmasında Ön İşlemlerin Etkisi
}

\author{
İbrahim DOYMAZ*1 \\ ${ }^{1}$ Yıldız Teknik Üniversitesi, Kimya-Metalürji Fakültesi, Kimya Mühendisliği Bölümü, \\ 34210, İstanbul
}

(Alınış / Received: 23.11.2016, Kabul / Accepted: 29.12.2017, Online Yayınlanma / Published Online: 15.05.2018)

\section{Anahtar Kelimeler}

Kara havuç,

Kurutma,

Rehidrasyon,

Diffüzyon katsayısı,

Aktivasyon enerjisi
Özet: Bu çalışmada, kara havuçların kurutma ve rehidrasyon parametrelerine ön işlemin ve sıcaklığın etkisi araştırılmıştır. Kara havuç dilimleri kabin kurutucusunda çeşitli sıcaklıklarda kurutuldu. Ön işlem ve hava sıcaklığının kurutma ve rehidrasyon koşullarını etkilediği gözlenmiştir. Kurutma eğrileri beș iyi bilinen matematiksel modele uydurulmuştur. Midilli ve Küçük modeli, tüm sıcaklık aralıkları için deneysel verilere en iyi uyum sağladığı saptanmıștır. Efektif difüzyon katsayısı değerleri $1.41 \times 10^{-8}$ $\mathrm{m}^{2} / \mathrm{s}$ ile $7.41 \times 10^{-8} \mathrm{~m}^{2} / \mathrm{s}$ arasında değişmektedir. Hesaplanan aktivasyon enerji değerleri sırasıly sıcak su (blanch), sodyum metabisülfat (SMB) ve kontrol numuneleri için 27.31, 29.54 ve $38.33 \mathrm{~kJ} /$ mol'dur.

\section{Impact of Pre-Treatments on Drying of Black Carrot}

\section{Keywords}

Black carrot, Drying,

Rehydration,

Diffusion coefficient, Activation energy

\begin{abstract}
The influence of pre-treatment and temperature on drying and rehydration parameters of black carrots was investigated in the study. The black carrot slices were dried at various temperatures in the cabinet dryer. It was observed that pre-treatment and air temperature were affected drying and rehydration conditions. The drying curves were fitted to five well-known mathematical models. The Midilli and Kucuk model best fitted the experimental data for the whole range of temperatures. The values of effective diffusivity ranged from $1.41 \times 10^{-8} \mathrm{~m}^{2} / \mathrm{s}$ to $7.41 \times 10^{-8} \mathrm{~m}^{2} / \mathrm{s}$. The calculated activation energy values were $27.31,29.54$ and $38.33 \mathrm{~kJ} / \mathrm{mol}$ for hot water (blanch), sodium metabisulphate (SMB) and control samples, respectively.
\end{abstract}




\section{Introduction}

Carrot (Daucus carota L.) is an important vegetable crop grown worldwide. China, Uzbekistan, Russian Federation, United States of America, Ukraine, Poland, United Kingdom, Japan, France and India are the major producing countries [1]. Carrot is an excellent source of $\beta$ carotenes, vitamin A and potassium, and it contains cholesterol-lowering pectin, vitamin $\mathrm{C}$, vitamin $\mathrm{B} 6$, thiamine, folic acid and magnesium [2].

Carrot varieties differ in colour from white to red, black, orange yellow and purple. It contain different combinations and quantities of macronutrients, fibre, vitamins, minerals and phytochemicals including carotenoids, phenolic acids, anthocyanins, isocoumarins, terpenes and sesquiterpenes [3]. Black or purple carrot (Daucus carota L. ssp. sativus var. atrorubens Alef.) originated from Turkey, Middle East and Far East [4]. They are commonly used in juices, candies, confectionery, ice cream, soft drinks, or other fermented beverages [5]. Carrot, like other vegetables, contains high amounts of water. For extending the availability of this product, some preservation processes can be used as freezing and drying. Drying is a classical method of carrot preservation which enables an extended shelf-life, lighter weight for transportation, and less space needed for storage [6]. Dried carrots are usually used in sauces, soups, pastries, spices, and other types of ready-made meals [7].

Grapes, plums, apricots, peppers, tomatoes and carrots are covered naturally with a thin-layer of wax. This outer layer offers benefits such as protection to the fruit or vegetable from environmental and external factors. The wax layer also affects the flow of moisture from inside of the fruit to its surface which is a crucial process in drying [8]. Prior to drying process, chemical dipping such as methyl and ethyl ester emulsions, aqueous solutions of sodium hydroxide, sodium chloride, potassium carbonate and calcium chloride have been used to overcome the wax barrier on fruits or vegetables [810]. Blanching is a common pretreatment for vegetable products. It not only induces the thermal inactivation of undesirable enzymes in vegetable tissue, including polyphenol oxidase, but also causes structural changes at a cellular level that result in a cell separation influencing the mass transfer phenomena during drying [11].

Although there have been some studies in the literature on the characteristics of orange carrot drying $[7,12,13]$, only one study has been conducted on the behavior of black carrot drying. Garba et al. (2015), the effect of blanching treatment $\left(98^{\circ} \mathrm{C}\right.$ for 3 and $\left.8 \mathrm{~min}\right)$ and air drying temperature of 40,50 and $60^{\circ} \mathrm{C}$ on drying characteristics of black carrot shreds were studied. They reported that drying temperature affected the drying rate but blaching did not have an effect on drying time. The present study was undertaken to determine the influence of pre-treatments (blanching and sodium metabisulphate solution) and drying temperature on drying time, drying rate, effective moisture diffusivity and activation energy and rehydration ratio of black carrots, and select the best mathematical model for describing the drying curves.

\section{Material and Method}

\subsection{Material}

Fresh black carrots (Daucus carota L.) were obtained from a local market in Konya, and stored in a refrigerated chamber in $4^{\circ} \mathrm{C}$ before the experiments. After washing, black carrots were peeled and sliced into about $3,6,9$ and $12 \mathrm{~mm}$ $( \pm 0.1)$ thick slices using a food slicer. Before drying process, the samples were pre-treated with sodium metabisulphate 
solution or blanched with hot water for inactivation of enzymes. The initial moisture content of the fresh carrot was determined using the AOAC method [14]. As a result, the initial moisture content of the fresh samples was determined to be as $8.33 \pm 0.05 \mathrm{~kg}$ water $/ \mathrm{kg}$ dry matter (d.b.).

\subsection{Dipping pre-treatment}

Black carrot slices were divided in three sample groups. One sample group were blanched (Blanch) in water at $85 \pm 1^{\circ} \mathrm{C}$ for 4 min. Other one sample group was dipped in sodium metabisulphate solution (SMB) which contained 3\% sodium metabisulphate at $20 \pm 1^{\circ} \mathrm{C}$ for 2 min. Another sample group dried as a control group (Control).

\subsection{Procedure of drying}

The drying of carrot slices was investigated in experimental cabinet dryer (APV \& PASILAC Limited of Carlisle, Cumbria, UK). The cabinet dryer was described previously by Doymaz [15]. Before drying experiments to achieve steady-state conditions for each drying run, the dryer was started about $0.5 \mathrm{~h}$. After this process, the samples was spread on the tray about $50 \pm 0.5 \mathrm{~g}$. The drying experiments were conducted at different temperatures of 45, 55, 65 and $75^{\circ} \mathrm{C}$ and constant air velocity of $2.0 \pm 0.1$ $\mathrm{m} / \mathrm{s}$. During drying, the sample weight was recorded at regular intervals of 15 min. Drying process was run until moisture content of about $0.10 \pm 0.02 \mathrm{~kg}$ water/kg dry matter (d.b.) was attained. Then, the dried products were cooled in the room temperature and then packed into in low density polyethylene bags which heat-sealed.

\subsection{Mathematical modelling of the drying curves}

Five thin-layer models listed in Table 1 were applied to describe drying kinetics of black carrot by fitting the experimental drying data of at different temperatures.

Table 1. Thin-layer drying models

\begin{tabular}{lll}
\hline Model name & Model & Ref. \\
\hline Lewis & $M R=\exp (-k t)$ & {$[16]$} \\
Henderson & $M R=\operatorname{aexp}(-k t)$ & {$[17]$} \\
and Pabis & $M R=\operatorname{axp}(-k t)+c$ & {$[18]$} \\
Logarithmic & $M R=\exp \left(-k t^{5}\right)$ & {$[19]$} \\
Page & $M R=\operatorname{axp}\left(-k t^{m}\right)+b t$ & {$[20]$} \\
Midilli & $M R=$ \\
and Kucuk & $M R=$ \\
\hline
\end{tabular}

The dimensionless moisture ratio $(M R)$ was calculated as:

$$
M R=\frac{M_{t}-M_{e}}{M_{0}-M_{e}}
$$

where $M_{t}, M_{0}$ and $M_{e}$ are moisture content at any time, initial moisture content, and equilibrium moisture content (kg water/kg dry matter), respectively, and $\mathrm{t}$ is drying time (min). The moisture ratio $(M R)$ was simplified to $M_{t} / M_{0}$ instead of $\left(M_{t}-M_{e}\right) /\left(M_{0}-M_{e}\right)$ [21] because of the values of $M_{e}$ small compared with $M_{t}$ or $M_{0}$ for long drying time.

The drying rate (DR) was calculated using Eq. (2):

$$
D R=\frac{M_{t}-M_{t+\Delta t}}{\Delta t}
$$

where $M_{t+\Delta t}$ is moisture content at $t+\Delta t$ (kg water/kg dry matter), and $\mathrm{t}$ is time (min).

\subsection{Data analysis}

The statistical analysis of the experimental data was done using Statistica 8.0.550 (StatSoft Inc., Tulsa, OK, USA) software package. The parameters of models were estimated using a nonlinear regression procedure based on the Levenberg-Marquardt algorithm. Coefficient of determination $\left(R^{2}\right)$, and reduced chi-square $\left(\chi^{2}\right)$ were useful 
parameters for selecting the most suitable drying model. These can be calculated as:

$$
\begin{array}{r}
R^{2}=1-\frac{\sum\left(M R_{p r e, i}-M R_{\text {exp } i}\right)^{2}}{\sum_{i=1}^{N}\left(\overline{M R}_{p r e}-M R_{\text {exp } i}\right)^{2}} \\
\chi^{2}=\frac{\sum_{i=1}^{N}\left(M R_{\text {expi }}-M R_{\text {pre }, i}\right)^{2}}{N-z}
\end{array}
$$

where $M R_{\text {exp }, i}$ and $M R_{\text {pre }, i}$ are experimental and predicted dimensionless moisture ratios, respectively; $N$ is number of observations; and $Z$ is number of constants. For quality fit, $R^{2}$ value should be higher and $\chi^{2}$ value should be lower $[22,23]$.

\subsection{Determination of effective moisture diffusivity}

Fick's second law of diffusion equation, symbolized as a mass-diffusion equation for drying agricultural products in a falling rate period, is shown in the following equation (5):

$$
\frac{\partial M}{\partial t}=\nabla\left[D_{\text {eff }}(\mathbf{V M})\right]
$$

For slab geometry, the solution of diffusion equation (Eq. 5) is solved by Crank [24], and supposed uniform initial moisture distribution, negligible external resistance, constant diffusivity and negligible shrinkage:

$$
\begin{aligned}
& M R=\frac{8}{\pi^{2}} \sum_{n=0}^{\infty} \frac{1}{(2 n+1)^{2}} \\
& \exp \left(-\frac{(2 n+1)^{2} \pi^{2} D_{e f f} t}{4 L^{2}}\right)
\end{aligned}
$$

where $D_{\text {eff }}$ is the effective moisture diffusivity $\left(\mathrm{m}^{2} / \mathrm{s}\right), L$ is the half-thickness of the slab (m), and $n$ is positive integer. As time increased, just the first term can be used to estimate the drying rate $(n=0)$, and then Eq. (6) converges into:

$$
M R=\frac{\mathbf{8}}{\pi^{2}} \exp \left(-\frac{\pi^{2} D_{\text {eff }} t}{4 L^{2}}\right)
$$

The values of effective moisture diffusivity are determined by the slope of a straight line when ln $(M R)$ versus time is plotted from (8):

$$
\text { Slope }=\frac{\pi^{2}}{4 L^{2}}
$$

\subsection{Computation of activation energy}

The dependence of the effective moisture diffusivity on temperature is generally by the Arrhenius equation [23]:

$$
D_{\text {eff }}=D_{0} \exp \left(-\frac{E_{a}}{R(T+273.15)}\right)
$$

Here $D_{0}, E_{a}, R$ and $T$ are the preexponential factor $\left(\mathrm{m}^{2} / \mathrm{s}\right)$, the activation energy $(\mathrm{kJ} / \mathrm{mol})$, the universal gas constant $(\mathrm{kJ} /(\mathrm{mol} \times \mathrm{K}))$, and temperature $\left({ }^{\circ} \mathrm{C}\right)$, respectively.

\subsection{Rehydration experiments}

Rehydration experiments for dried samples (about $2.0 \mathrm{~g}$ ) were carried out in $300 \mathrm{~mL}$ distilled water bath at $20^{\circ} \mathrm{C}$. The total rehydration time was $300 \mathrm{~min}$. After this time, the samples were removed from the liquid, and excess water was blotted with tissue paper on the surface, and weighed with a digital balance (Precisa, model XB220A, Precisa Instruments AG, Dietikon, Switzerland) having a sensitivity of $0.001 \mathrm{~g}$. The rehydration ratio (RR) was calculated according to Eq. (10):

$$
R R=\frac{W_{2}-W_{1}}{W_{1}}
$$

where $W_{1}$ is the weight of dried matter $(\mathrm{kg})$ and $W_{2}$ is the weight of sample $(\mathrm{kg})$. 


\section{RESULTS}

\subsection{Effect of temperature}

The effect of four temperatures on the drying curves of black carrot slices is presented in Figure 1. As can be seen, the increase in air temperature resulted in a decrease in the drying time. From the Figure 1, the drying time of control code samples reduced from 480 to $135 \mathrm{~min}$ when the air temperature was increased from 45 to $75^{\circ} \mathrm{C}$. Similar results were seen in pre-treated samples dried at same temperatures. These results agreed with the findings of Özdemir et al. [8] for golden berry, Khanali et al. [25] for rough rice, Xiao et al. [12] for black carrot cubes and Garba et al. [2] for purple carrot slices.

\subsection{Influence of pre-treatment}

According to Figure 1, pre-treatment is one of important parameters that affects the drying time. The samples blanched with hot water (blanch code) prior to drying were found to have a shorter drying time compared to SMB and control samples. The drying time required reaching final water content ( $0.10 \mathrm{~kg}$ water $/ \mathrm{kg}$ dry matter) for SMB and control samples were 390 and 480 $\min$ at $45^{\circ} \mathrm{C}$, respectively. For the blanched samples, this value was 210 $\min$ at the same temperature. The drying time of blanched samples were found to be $46.15 \%$ and $56.25 \%$ shorter when compared to the drying times of SMB and control samples, respectively. These results show that the process of blanched with hot water contributed to increase the permeability of the cell membranes of samples, leading to an increase in water diffusivity. Similar results were found in the samples dried at other temperatures. The effect of pretreatment on drying time was also reported for different vegetables and fruits $[8,9,26,27]$.

\subsection{Slice thickness}

Figure 2 shows the drying curves of control slices at $65^{\circ} \mathrm{C}$ for different slice thicknesses. It is clearly evident from these curves that the drying rate was higher at thin slices, and the total drying time reduced substantially with the decrease in slice thickness. The drying times of control samples were 180, 375, 420 , and $480 \mathrm{~min}$, respectively, in relation to the slice thickness of $3,6,9$ and $12 \mathrm{~mm}$. The drying time of $3 \mathrm{~mm}$ slice thickness samples was shortened by $108.33 \%, \quad 133.33 \%$, and $166.66 \%$ compared with the drying process realized at 6,9 , and $12 \mathrm{~mm}$ slice thickness samples, respectively. Thinly sliced products dried faster due to the reduced distance the moisture travels and increased surface area exposed for a given volume of the product. The similar findings were reported by Ertekin and Yaldiz [28] for hot-air drying of eggplant slices and Wu et al. [29] for infrared and hot-air drying of carrot slices.

\subsection{Drying rate}

The drying rates of dried at different temperatures were calculated using Eq. (2) and are shown in Figure 3. It is observed that drying rate decreased continuously with improving drying time. The drying rate reached its maximum values at higher drying air temperatures. The moisture removal inside the black carrot slices was higher at higher air temperatures. So, the migration of moisture to the surface and the evaporation rate from surface to air slows down with decreasing the moisture in the product, the drying rate clearly decrease (Figure 3). As can be seen no constant drying rate period was observed, and the whole drying process occurred in the falling drying rate period. This shows that diffusion in dominant physical mechanism governing moisture movement in the samples. Similar results are reported by different researchers on 
drying various biological products $[7,26,29]$.

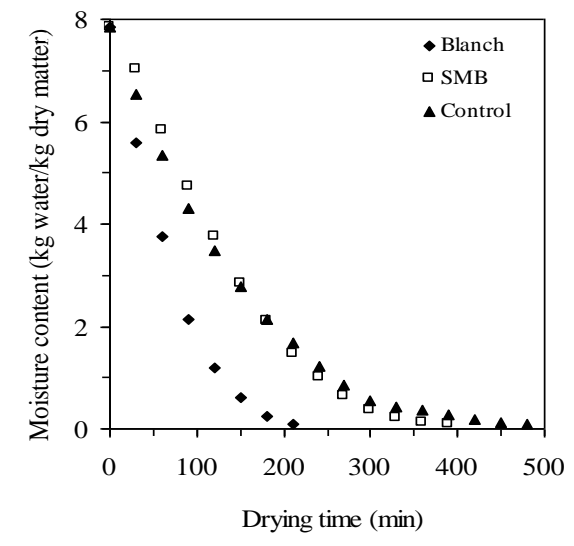

(A)

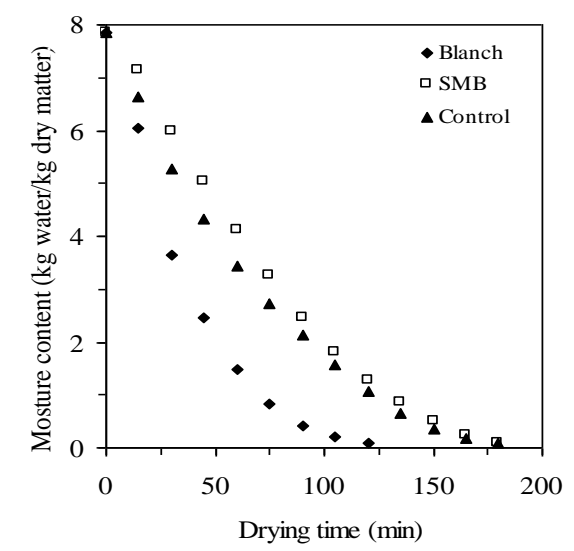

(C)

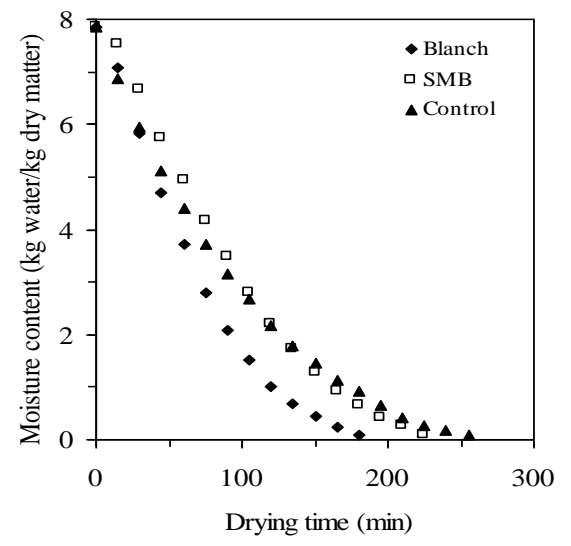

(B)

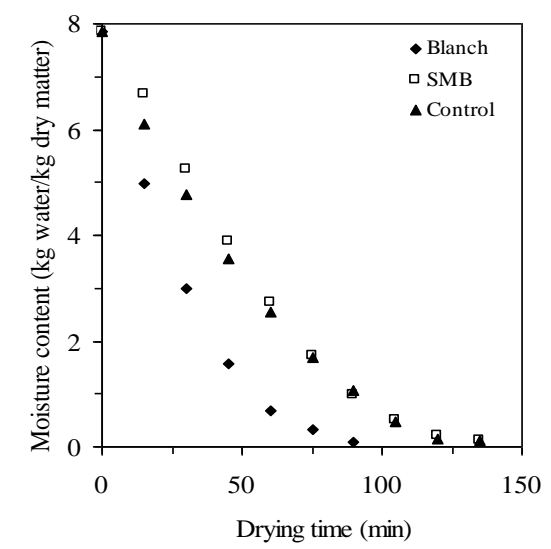

(D)

Figure 1. Drying curves of black carrot slices (d: $3 \mathrm{~mm}$ ) with and without pretreatments at different temperatures $\left(\mathrm{A}: 45^{\circ} \mathrm{C}, \mathrm{B}: 55^{\circ} \mathrm{C}, \mathrm{C}: 65^{\circ} \mathrm{C}\right.$ and $\left.\mathrm{D}: 75^{\circ} \mathrm{C}\right)$

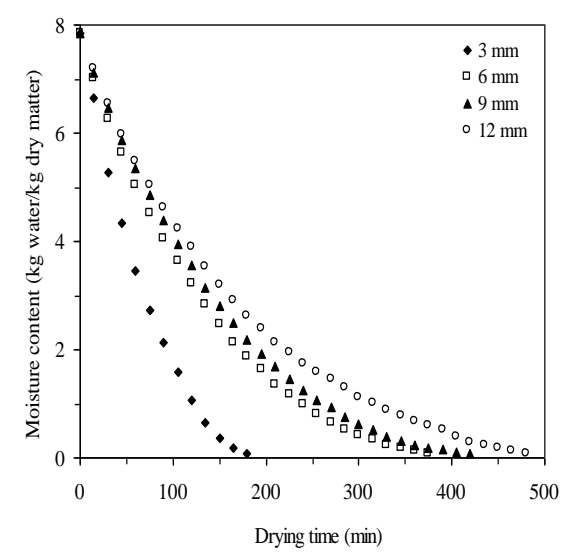

Figure 2. Drying curves of control black carrot slices (control code) at different slice thicknesses at $65^{\circ} \mathrm{C}$ 


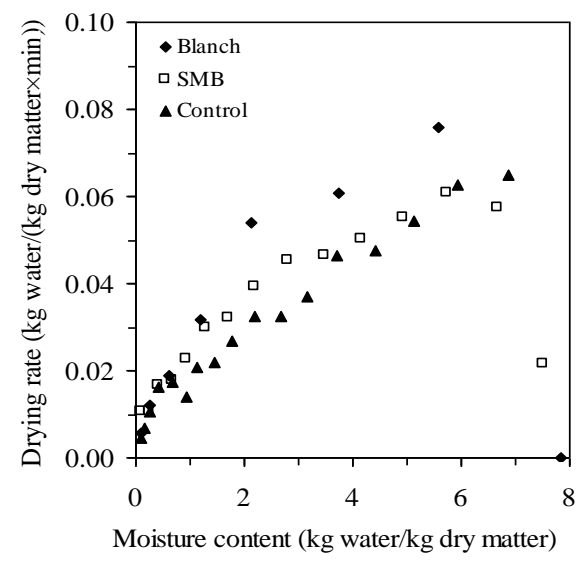

(A)

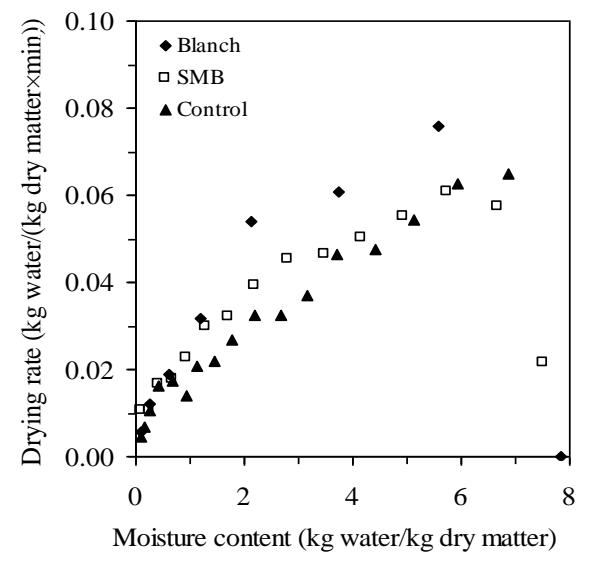

(C)

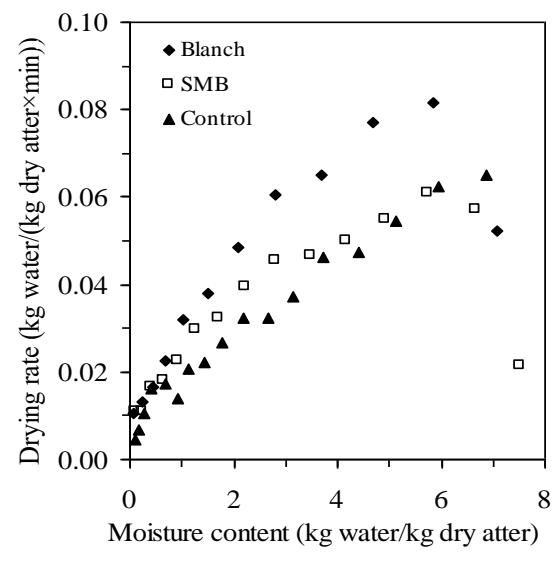

(B)

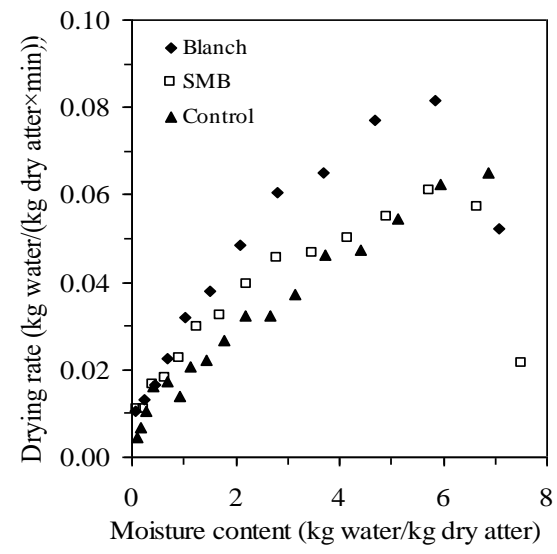

(D)

Figure 3. Drying rate versus drying time of black carrot slices $(\mathrm{d}: 3 \mathrm{~mm})$ at different temperatures $\left(\mathrm{A}: 45^{\circ} \mathrm{C}, \mathrm{B}: 55^{\circ} \mathrm{C}, \mathrm{C}: 65^{\circ} \mathrm{C}\right.$ and $\mathrm{D}: 75^{\circ} \mathrm{C}$ )

\subsection{Modeling of drying curves}

The thin-layer drying models in Table 1 were used to describe the drying of black carrot slices. The results of statistical analysis results of model fitting are summarized in Table 2. Based on the statistical parameters for each model, it can be concluded that the Midilli and Kucuk model gave the best representation of experimental data of black carrot slices. The values of $R^{2}, \chi^{2}$, and RMSE for the Midilli and Kucuk model vary between 0.9984 and 0.9999 , 0.000008 and 0.000312 , and 0.00740 and 0.03086, respectively. Figures 4 compare the experimental data with the predicted ones using different models for black carrot slices at 45, 55, 65 and $75^{\circ} \mathrm{C}$. The predictions using the Midilli and Kucuk model showed MR values banded along a straight line, which proved the suitability of this model in describing the drying characteristics of black carrot slices. 
Table 2. Statistical values of thin-layer drying of black carrot slices

\begin{tabular}{|c|c|c|c|c|}
\hline Code & $\mathrm{T}\left({ }^{\circ} \mathrm{C}\right)$ & Model name & $\mathrm{R}^{2}$ & $\chi^{2}$ \\
\hline \multirow{20}{*}{ Blanch } & \multirow[t]{5}{*}{45} & Lewis & 0.9865 & 0.001732 \\
\hline & & Henderson and Pabis & 0.9862 & 0.001766 \\
\hline & & Logarithmic & 0.9970 & 0.000537 \\
\hline & & Page & 0.9991 & 0.000128 \\
\hline & & Midilli and Kucuk & 0.9995 & 0.000071 \\
\hline & \multirow[t]{5}{*}{55} & Lewis & 0.9686 & 0.003661 \\
\hline & & Henderson and Pabis & 0.9780 & 0.002800 \\
\hline & & Logarithmic & 0.9947 & 0.000737 \\
\hline & & Page & 0.9995 & 0.000056 \\
\hline & & Midilli and Kucuk & 0.9999 & 0.000008 \\
\hline & \multirow[t]{5}{*}{65} & Lewis & 0.9851 & 0.001861 \\
\hline & & Henderson and Pabis & 0.9877 & 0.001745 \\
\hline & & Logarithmic & 0.9940 & 0.000990 \\
\hline & & Page & 0.9984 & 0.000227 \\
\hline & & Midilli and Kucuk & 0.9984 & 0.000312 \\
\hline & \multirow[t]{5}{*}{75} & Lewis & 0.9924 & 0.001016 \\
\hline & & Henderson and Pabis & 0.9930 & 0.001121 \\
\hline & & Logarithmic & 0.9986 & 0.000262 \\
\hline & & Page & 0.9990 & 0.000159 \\
\hline & & Midilli and Kucuk & 0.9995 & 0.000124 \\
\hline \multirow[t]{20}{*}{ SMB } & \multirow[t]{5}{*}{45} & Lewis & 0.9674 & 0.003838 \\
\hline & & Henderson and Pabis & 0.9766 & 0.002986 \\
\hline & & Logarithmic & 0.9932 & 0.000939 \\
\hline & & Page & 0.9993 & 0.000085 \\
\hline & & Midilli and Kucuk & 0.9997 & 0.000038 \\
\hline & \multirow[t]{5}{*}{55} & Lewis & 0.9522 & 0.005563 \\
\hline & & Henderson and Pabis & 0.9691 & 0.003845 \\
\hline & & Logarithmic & 0.9941 & 0.000792 \\
\hline & & Page & 0.9990 & 0.000121 \\
\hline & & Midilli and Kucuk & 0.9997 & 0.000035 \\
\hline & \multirow[t]{5}{*}{65} & Lewis & 0.9602 & 0.004650 \\
\hline & & Henderson and Pabis & 0.9711 & 0.003678 \\
\hline & & Logarithmic & 0.9959 & 0.000570 \\
\hline & & Page & 0.9982 & 0.000229 \\
\hline & & Midilli and Kucuk & 0.9997 & 0.000033 \\
\hline & \multirow[t]{5}{*}{75} & Lewis & 0.9616 & 0.004919 \\
\hline & & Henderson and Pabis & 0.9695 & 0.004390 \\
\hline & & Logarithmic & 0.9931 & 0.001122 \\
\hline & & Page & 0.9985 & 0.000214 \\
\hline & & Midilli and Kucuk & 0.9994 & 0.000102 \\
\hline
\end{tabular}


Table 2. Statistical values of thin-layer drying of black carrot slices-cont.

\begin{tabular}{lcccc}
\hline Code & $T\left({ }^{\circ} \mathrm{C}\right)$ & Model name & $R^{2}$ & $\chi^{2}$ \\
\hline Control & 45 & Lewis & 0.9930 & 0.000675 \\
& Henderson and Pabis & 0.9945 & 0.000562 \\
& Logarithmic & 0.9981 & 0.000209 \\
& Page & 0.9990 & 0.000095 \\
& Midilli and Kucuk & 0.9993 & 0.000081 \\
& & & \\
& 55 & Lewis & 0.9879 & 0.001164 \\
& Henderson and Pabis & 0.9904 & 0.000978 \\
& Logarithmic & 0.9997 & 0.000032 \\
& Page & 0.9974 & 0.000264 \\
& Midilli and Kucuk & 0.9998 & 0.000017 \\
& & & \\
& Lewis & 0.9836 & 0.001743 \\
& Henderson and Pabis & 0.9867 & 0.001547 \\
& Logarithmic & 0.9990 & 0.000119 \\
& Page & 0.9963 & 0.000427 \\
& Midilli and Kucuk & 0.9993 & 0.000098 \\
& & & \\
& Lewis & 0.9804 & 0.002293 \\
& Henderson and Pabis & 0.9828 & 0.002263 \\
& Logarithmic & 0.9983 & 0.000255 \\
& Page & 0.9953 & 0.000617 \\
& Midilli and Kucuk & 0.9987 & 0.000228 \\
\hline
\end{tabular}

\subsection{Effective moisture diffusivity}

The values of effective moisture diffusivity ( $\left.D_{\text {eff }}\right)$ at different drying conditions were calculated using Eq. (8), as shown in Figure 5. They were found to range between $1.41 \times 10^{-8}$ and $7.41 \times 10^{-8} \mathrm{~m}^{2} / \mathrm{s}$. From Figure 5 , it can be seen that the $D_{\text {eff }}$ increased greatly with increasing drying temperature. This reduces the drying time significantly. The increase of air temperature resulted in fast heating of the black carrot slices and the vapor pressure in the carrot slices increased which speed up the moisture diffusion to the samples surface. The $D_{\text {eff }}$ values are close to the values of $2.65 \times 10^{-10}$ to $1.052 \times 10^{-9} \mathrm{~m}^{2} / \mathrm{s}$ reported for the hot-air drying of carrot cubes at 40 to $60^{\circ} \mathrm{C}$ [12], $1.35 \times 10^{-9}$ to $3.45 \times 10^{-9} \mathrm{~m}^{2} / \mathrm{s}$ for the hot-air drying of carrot slices at 50 to $70^{\circ} \mathrm{C}$ [30], $1.43 \times 10^{-9}$ to $5.50 \times 10^{-9} \mathrm{~m}^{2} / \mathrm{s}$ for the hotair drying of carrot slices at 60 to $80^{\circ} \mathrm{C}$ [29], $1.3 \times 10^{-9}$ to $2.6 \times 10^{-9} \mathrm{~m}^{2} / \mathrm{s}$ for the hot-air drying of black carrot slices at 40 to $60^{\circ} \mathrm{C}$ [2]. The $D_{\text {eff }}$ values obtained from this study are in agreement with the literature values although some differences exist. The differences between the results could be due to the initial moisture content, composition structure and shape material, besides the dryer type, air temperature, and pre-treatments. 


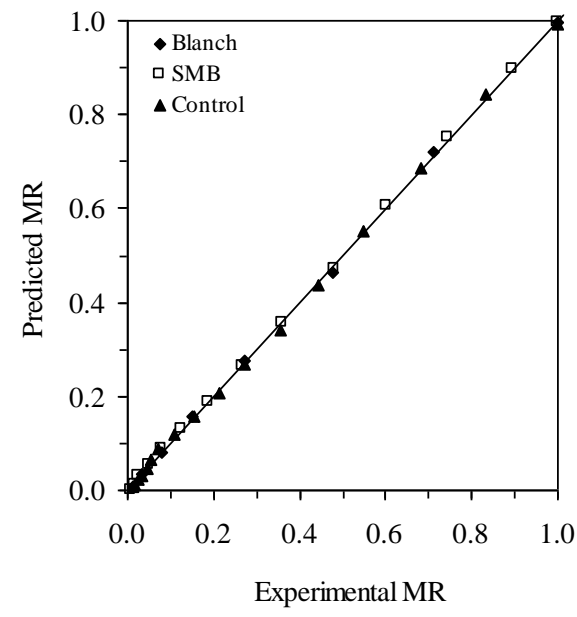

(A)

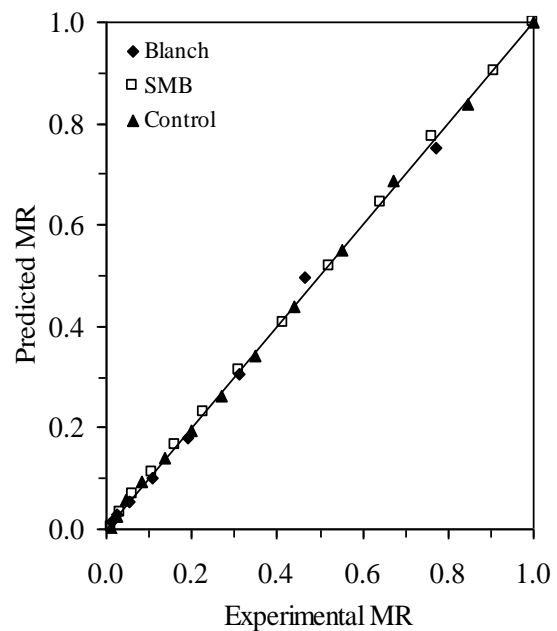

(C)

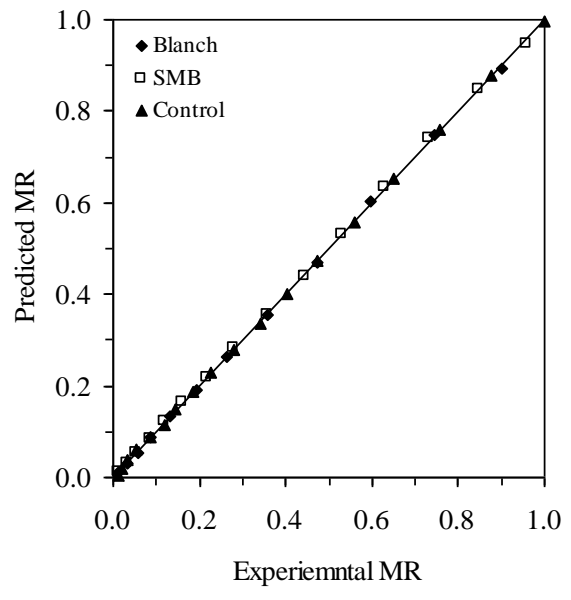

(B)

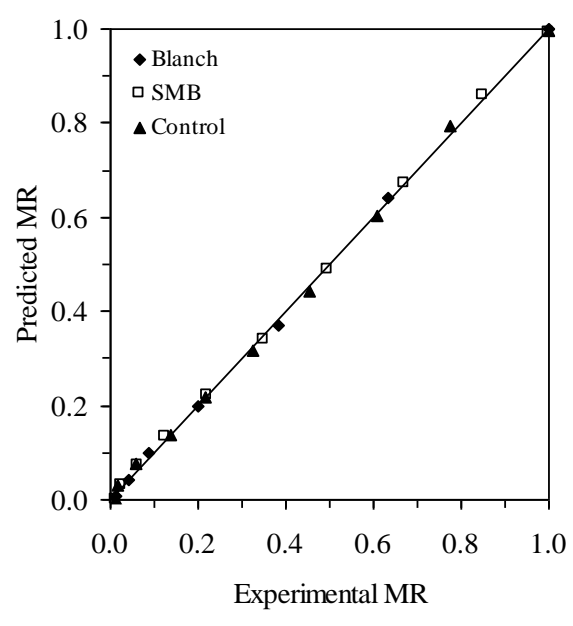

(D)

Figure 4. Comparison of experimental and predicted moisture ratio values using Midilli and Kucuk model (A: $45^{\circ} \mathrm{C}, \mathrm{B}: 55^{\circ} \mathrm{C}, \mathrm{C}: 65^{\circ} \mathrm{C}$ and $\mathrm{D}: 75^{\circ} \mathrm{C}$ ) 


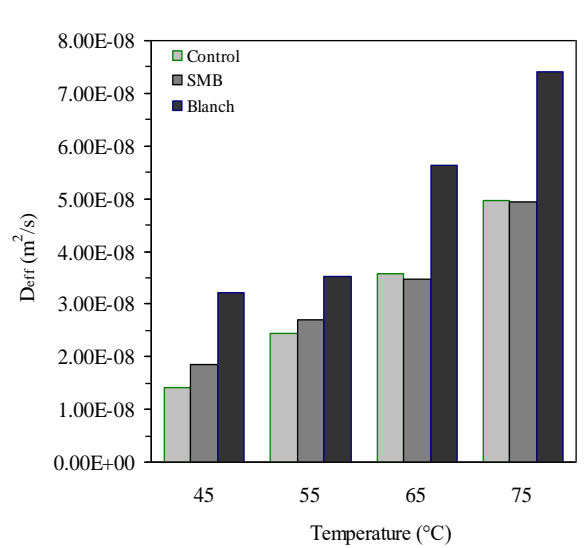

Figure 5. Variation of effective moisture diffusivity with air-drying temperature

\subsection{Activation energy}

The values of activation energy were calculated by using Eq. (9), as shown in Figure 6. Eqs. (11), (12), and (13) show the effect of temperature on $D_{\text {eff }}$ of the samples with following coefficients:

Blanch code:

$$
\begin{aligned}
& D_{\text {sff }}=9.052 \times 10^{-4} \exp \left(-\frac{3285.6}{(T+273.15)}\right)(11 \\
& \left(R^{2}: 0.9405\right)
\end{aligned}
$$

SMB code:

$$
\begin{aligned}
& \left.D_{\text {aff }}=1.312 \times 10^{-3} \exp \left(-\frac{3553.5}{(T+273.15)}\right){ }_{12}\right) \\
& \left(R^{2}: 0.9951\right)
\end{aligned}
$$

Control code:

$$
\begin{aligned}
& D_{\text {aff }}=2967 \times 10^{-2} \exp \left(-\frac{4617.1}{(T+273.15)}\right)(13) \\
& \left(R^{2}: 0.9918\right)
\end{aligned}
$$

Using these equations $(11,12$, and 13$)$, the activation energy values were found to be $27.31,29.54$ and $38.33 \mathrm{~kJ} / \mathrm{mol}$ for blanch, SMB and control samples, respectively. This result is in agreement with findings of Garba et al. [2], who reported similar trend of decreasing activation energy of the blanched samples of black carrot shreds in comparison with the unblanched samples. The values of the activation energy vary from 12.7 to $110 \mathrm{~kJ} / \mathrm{mol}$ for most food materials [31]. The similar values to those proposed in the literature for drying of orange carrots: $35.74-59.06 \mathrm{~kJ} / \mathrm{mol}$ for infrared drying of carrot slices [29], 23.63-33.24 kJ/mol hot-air drying of carrot slices [29], and $20.17 \mathrm{~kJ} / \mathrm{mol}$ for hot-air drying of carrot slices [12].

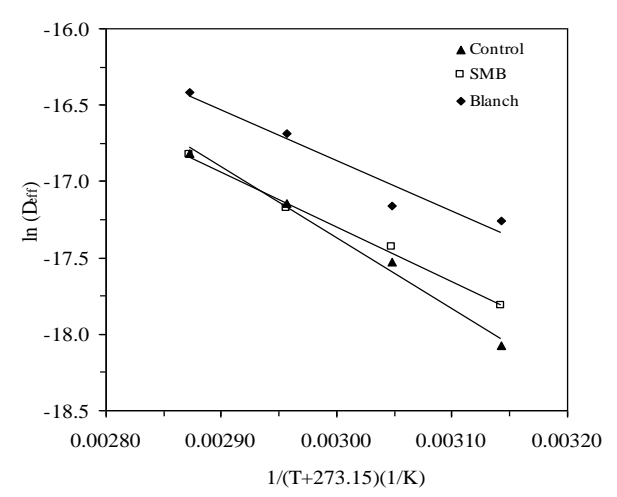

Figure 6. Arrhenius-type relationship between effective moisture diffusivity $\left(D_{\text {eff }}\right)$ and air-drying temperature

\subsection{Rehydration ratio}

Rehydration characteristics are utilized as a parameter to determine quality because these are indicative of the degree of alterations occurring during processing such as pre-treatments, drying, and rehydration. Rehydration process depends on structural changes in vegetable tissues and cells of food material during drying process, which produces shrinkage and collapse and reduces the rehydration ratio, thus preventing complete rehydration of the dried product [32]. The rehydration ratio values of samples at different rehydration temperatures, calculated from Eq. (10) are shown in Figure 7.

It can be seen that the values of rehydration ratio was affected by the air temperatures, because absorbed water decreased with drying temperature. The lowest rehydration ratio values were obtained the samples dried at $75^{\circ} \mathrm{C}$, this 
could be explained due to cellular structure damage resulting in modifications of osmotic properties of the cell as well as lower diffusion of water through the surface during rehydration [33]. As seen in Figure 7, the rehydration ratio of SMB samples resulted in the highest rehydration, compared to blanched and control samples. This result can be attributed to the fact that cellular and structural deterioration in carrot slices dried by SMB solution is less than in other samples. This can be achieved as a result of increasing the rehydration ratio.

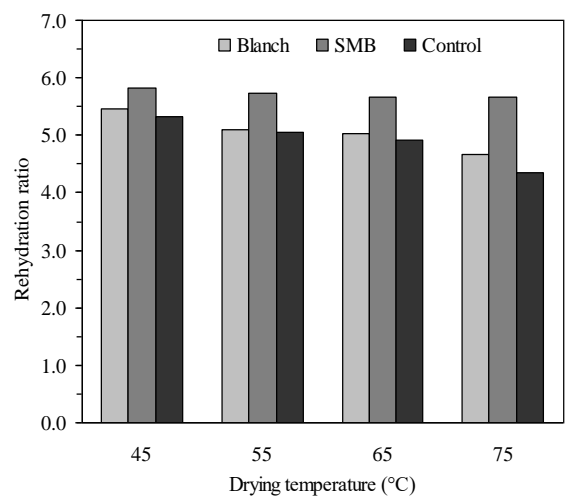

Figure 7. Rehydration ratio versus drying temperature at rehydration temperature of $20^{\circ} \mathrm{C}$.

\section{DISCUSSION AND CONCLUSION}

In the study, the influence pretreatment and air temperature on drying characteristics of black carrot slices were investigated. The drying time was shortened with air temperature increase. The blanching pre-treatment accelerated the drying process as a result of tissue softening. The whole drying process occurred in the falling drying rate period. Five thinlayer models were used to predict drying kinetics by nonlinear analysis of regression. The Midilli and Kucuk model best fitted the experimental data for all temperatures. The effective moisture diffusivity was found in the range of $1.41 \times 10^{-8}$ to $7.41 \times 10^{-8} \mathrm{~m}^{2} / \mathrm{s}$ as the air temperature increased from 45 to $75^{\circ} \mathrm{C}$. The values of activation energy were determined to be 27.31, 29.54, and $38.33 \mathrm{~kJ} / \mathrm{mol}$ for blanch, SMB and control samples, respectively. As a result of pre-treatments applied prior to drying, high drying rate, effective moisture diffusivity and rehydration ratio, and low activation energy amount and drying time are given.

\section{REFERENCES}

[1] FAO, FaoStat: Agriculture data. http://www.fao.org/faostat/en/\#d ata/QC (Updated: December 15, 2017).

[2] Garba, U., Kaur, S., Gurumayum, S., Rasane, P. 2015. Effect of Hot Water Blanching Time and Drying Temperature on the Thin Layer Drying Kinetics and Anthocyanin Degradation of Black Carrot (Daucus carota l.) Shreds, Food Technology and Biotechnology, Cilt. 53, s. 324-330.

DOI: $10.17113 / \mathrm{ft}$ b.53.03.15.3830

[3] Poudyal, H., Panchal, S., Brown, L. 2010. Comparison of Purple Carrot Juice and B-carotene in a HighCarbohydrate, High-Fat Diet-Fed Rat Model of the Metabolic Syndrome, British Journal of Nutrition, Cilt. 104, s. 1322-1332. DOI: $0.1017 / \mathrm{S} 0007114510002308$

[4] Unal, M.U., Bellur, E. 2009. Extraction and Characterisation of Pectin Methlesterase from Black Carrot (Daucus carota L.), Food Chemistry, Cilt. 116, s. 836-840. DOI: 10.1016/j.foodchem.2009.03.031

[5] Montilla, E.C., Azaba, M.R., Hillebrand, S., Winterhalter, P.. 2011. Anthocyanin Composition of Black Carrot (Dauces carota ssp. sativus var. atrorubens Alef.) Cultivars Antonina, Beta Sweet, Deep Purple, and Purple Haze, 
Journal of Agricultural and Food Chemistry, Cilt. 59, s. 3585-3590. DOI: $10.1021 / \mathrm{jf104724 \textrm {k }}$

[6] Ando, Y., Maeda, Y., Mizutani, K., Wakatsuki, N., Hagiwara, S., Nabetani, H. 2016. Impact of Blanching and Freeze-Thaw Pretreatment on Drying Rate of Carrot Roots in Relation to Changes in Cell Membrane Function and Cell Wall Structure, LWT - Food Science and Technology, Cilt. 71, s. 40-46. DOI: 10.1016/j.lwt.2016.03.019

[7] Zielinska, M., Markowski, M. 2010. Air Drying Characteristics and Moisture Diffusivity of Carrots, Chemical Engineering and Processing, Cilt. 49, s. 212-218. DOI: 10.1016/j.cep.2009.12.005

[8] Ozdemir, Y., Ozturk, A., Tufekci, S. 2016. Effect of Two Dipping Pretreatment on Drying Kinetics of Golden Berry (Physalis peruviana L.), African Journal of Agricultural Research, Cilt. 11, s. 40-47. DOI: 10.5897/AJAR2014.8937

[9] Doymaz, I., Pala, M. 2003. Effect of Ethyl Oleate on Drying Characteristics of Mulberries, Nahrung/Food, Cilt. 47, s. 304-308. DOI: $10.1002 /$ food.200390071

[10] Zhao, D., Wang, Y., Zhu, Y., Ni, Y. 2016. Effect of Carbonic Maceration Pre-Treatment on Drying Behaviour and Physicochemical Compositions of Sweet Potato Dried with Intermittent or Continuous Microwave, Drying Technology, Cilt. 34 , s. 1604-1612. DOI: 10.1080/07373937.2016.1138231

[11] Ahmad-Qasem, M.H., Nijsse, J., García-Pérez, J.V., Khalloufi, S. 2016. The Role of Drying Methods on Enzymatic Activity and Phenolic Content of Impregnated Dried Apple, Drying Technology, Cilt. 35, s. $1204-1213$. DOI: 10.1080/07373937.2016.1236344
[12] Xiao, H.W., Gao, Z.J., Lin, H., Yang, W.X. 2010. Air Impingement Drying Characteristics and Quality of Carrot Cubes, Journal of Food Process Engineering, Cilt. 33, s. 899-918. DOI: $10.1111 / \mathrm{j} .1745-$ 4530.2008.00314.x

[13] Demiray, E., Tulek, Y. 2015. Color Degradation Kinetics of Carrot (Daucus carota L.) Slices during Hot Air Drying, Journal of Food Processing and Preservation, Cilt. 39, s. 800-805. DOI: 10.1111/jfpp.12290

[14] AOAC. 1990. Official method of analysis, Association of Official Analytical Chemists, Arlington, VA.

[15] Doymaz, I. 2005. Drying Characteristics and Kinetics of Okra, Journal of Food Engineering, Cilt. 69, s. 275-279. DOI: 10.1016/j.jfoodeng.2004.08.019

[16] Zanoelo, E.F., Di Celso, G.M., Kaskantzis, G. 2007. Drying Kinetics of Mate Leaves in a Packed Bed Dryer, Biosystems Engineering, Cilt. 96, s. 487-494. DOI: 10.1016/j.biosystemseng.2006.12. 006

[17] Henderson, S.M., Pabis, S. 1961. Grain Drying Theory. II. Temperature Effects on Drying Coefficients, Journal of Agricultural Engineering Research, Cilt. 6, s. 169-174.

[18] Afolabi, T.J., Tunde-Akintunde, T.Y., Adeyanju, J.A. 2015. Mathematical Modeling of Drying Kinetics of Untreated and Pretreated Cocoyam Slices, Journal of Food Science and Technology, Cilt 52, s. 2731-2740. DOI: 10.1007/s13197-014-1365-z.

[19] Cai, J., Chen, S. 2008. Determination of Drying Kinetics for Biomass by Thermogravimetric Analysis under Nonisothermal Condition, Drying Technology, Cilt. 26, s. 1464-1468. DOI: 10.1080/07373930802412116 
[20] Midilli, A., Kucuk, H. 2003. Mathematical Modeling of Thin Layer Drying of Pistachio by using Solar Energy, Energy Conversion and Management, Cilt. 44, s. 11111122. DOI: $10.1016 /$ S01968904(02)00099-7

[21] Ismail, O., Kanturk Figen, A., Piskin, S. 2015. Effects of Open-Air Sun Drying and Pre-Treatment on Drying Characteristics of Purslane (Portulaca oleracea L.), Heat and Mass Transfer, Cilt. 51, s. 807-813. DOI: $10.1007 / \mathrm{s} 00231-014-1452-8$

[22] Zhang, Y., Duan, K., Song, F., Chen W., Zhao, S. 2016. Drying Characteristics and Heat Requirement of Coconut Endocarp Determined by Simultaneous Thermal Analyser, Heat and Mass Transfer, Cilt. 52, s. 1891-1898. DOI: $10.1007 / \mathrm{s} 00231-015-1701-5$

[23] Akpinar, E.K., Toraman, S. 2016. Determination of Drying Kinetics and Convective Heat Transfer Coefficients of Ginger Slices, Heat and Mass Transfer, Cilt. 52, s. 22712281. DOI: $10.1007 / s 00231-015-$ 1729-6

[24] Crank, J. 1975. The Mathematics of Diffusion, 2nd, Oxford University Press, London, 347s.

[25] Khanali, M., Banisharif, A., Rafiee, S. 2016. Modeling of Moisture Diffusivity, Activation Energy and Energy Consumption in Fluidized Bed Drying of Rough Rice, Heat and Mass Transfer, Cilt. 52, s. 25412549. DOI: $10.1007 / \mathrm{s} 00231-016-$ 1763-z

[26] Nahimana, H., Mujumdar, A.S., Zhang, M. 2011. Drying and Radial Shrinkage Characteristics and Changes in Color and Shape of Carrot Tissues (Daucus carota L) during Air Drying, African Journal of Biotechnology, Cilt. 10, s. 1532715345. DOI: 10.5897/AJB11.576

[27] Bi, J., Yang, A., Liu, X., Wu, X., Chen, Q., Wang, Q., Lv, J., Wang, X. 2015.
Effects of Pretreatments on Explosion Puffing Drying Kinetics of Apple Chips, LWT - Food Science and Technology, Cilt. 60, s. 11361142. DOI: 10.1016/j.lwt.2014.10.006

[28] Ertekin, C., Yaldiz, O. 2004. Drying of Eggplant and Selection of a Suitable Thin Layer Drying Model, Journal of Food Engineering, Cilt. 63, s. 349-359. DOI: 10.1016/j.jfoodeng.2003.08.007

[29] Wu, B., Ma, H., Qu, W., Wang, B., Zhang, X., Wang, P., Wang, J., Atungulu, G.G., Pan, Z. 2014. Catalytic Infrared and Hot Air Dehydration of Carrot Slices, Journal of Food Process Engineering, Cilt. 37, s. 111-121. DOI: $10.1111 /$ jfpe.12066

[30] Liu, Y., Wu, J., Miao, S., Chong, C., Sun, Y. 2014. Effect of a Modified Atmosphere on Drying and Quality Characteristics of Carrots, Food and Bioprocess Technology, Cilt. 7, s.2549-2559. DOI: $10.1007 / s 11947-014-1295-9$

[31] Zogzas, N.P., Maroulis, Z.B., Marinos-Kouris, D. 1996. Moisture Diffusivity Data Compilation in Foodstuff, Drying Technology, Cilt. 14 , s. 2225-2253. DOI: 10.1080/07373939608917205

[32] Gan, S.H., Ong, S.P., Chin, N.L., Law, C.L. 2015. Color Changes, Nitrite Content, and Rehydration Capacity of Edible Bird's Nest by Advanced Drying Method, Drying Technology, Cilt. 34 , s. 1330-1342. DOI: 10.1080/07373937.2015.110655

[33] Kaymak-Ertekin, F. 2002. Drying and Rehydrating Kinetics of Green and Red Peppers, Journal of Food Science, Cilt. 67, s. 168-175. DOI: $\quad 10.1111 / \mathrm{j} .1365$ 2621.2002.tb11378.x 